九州大学学術情報リポジトリ

Kyushu University Institutional Repository

Physicochemical Properties and Fertility Index of Culture Media Containing Distillery Residue Biochar and Their Applications to Plug Seedling

KUO, We i-Ru

Department of Horticulture, College of Agriculture, National Chiayi University

YEH, Nien-Chia

Graduate Institute of Wood Based Materials and Design, College of Agriculture, National Chiayi University

FUJIM0T0, Noboru

Laboratory of Wood Material Technology, Division of Sustainable Bioresources Science, Department of Agro-environmental Sciences, Faculty of Agriculture, Kyushu University

LIN, Han Chien

Laboratory of Environment Functional Materials, Department of Wood Based Materials and Design, College of Agriculture, National Chiayi University

https://doi.org/10.5109/2232296

出版情報：九州大学大学院農学研究院紀要. 64 (1)，pp. 127-135，2019-02-28. Faculty of Agriculture, Kyushu University

バージョン :

権利関係 : 


\title{
Physicochemical Properties and Fertility Index of Culture Media Containing Distillery Residue Biochar and Their Applications to Plug Seedling
}

\author{
Wei-Ru KUO ${ }^{1}$, Nien-Chia YEH ${ }^{2}$, Noboru FUJIMOTO, Han Chien LIN ${ }^{3 *}$ \\ Laboratory of Wood Material Technology, Division of Sustainable Bioresources Science, \\ Department of Agro-environmental Sciences, Faculty of Agriculture, \\ Kyushu University, Fukuoka 819-0395, Japan \\ (Received October 31, 2018 and accepted November 12, 2018)
}

\begin{abstract}
Sorghum distillery residue (SDR) was derived into sorghum distillery residue biochar (SDRBC) at carbonization temperatures of 300,450 , and $600^{\circ} \mathrm{C}$ with the duration time at 0 and $60 \mathrm{~min}$, in order to investigate physicochemical properties, fertility index, and seedling index in the seedling period and to evaluate the effect of the culture media containing SDRBC on the quality of vegetable plug seedling. The $\mathrm{pH}$ of SDRBC increased with the increase of carbonization temperature, but the electrical conductivity (EC) decreased as the carbonization temperature decreased. The cation exchange capacity of SDRBC was high when SDRBC prepared from the low carbonization temperature with $0 \mathrm{~min}$. The $\mathrm{C}$ element content in various SDRBCs was 62.05-74.13\%, increasing with carbonization temperature. The SDRBC with high carbonization temperature had a smaller O/C with hydrophilic and weaker polarity. The FTIR results of SDRBC with low carbonization temperature had C-H stretching vibration hydrophilic functional group at $2926 \mathrm{~cm}^{-1}$. The physical properties of the culture media containing SDRBC met the requirements for general perfect medium. The $\mathrm{pH}$ of chemical properties was $5.64-6.32$, and the EC was $0.30-0.50 \mathrm{dS} / \mathrm{m}$. The fertility index in the seedling period of the culture media containing SDRBC increased with the volume ratio of SDRBC and was higher than the peat with perlite, whereas the case without duration time ( 0 min) had higher seedling index (I) and (II) than the case with duration time for $60 \mathrm{~min}$.
\end{abstract}

Key words: Sorghum Distillery Residue (SDR), Biochar, Plug Seedling, Fertility Index, Seedling Index

\section{INTRODUCTION}

Biochar can be used as a low cost adsorbent (Ioannidou and Zabaniotou, 2007) or modifier for improving soil fertility (Lehmann et al., 2006; Bustamante et al., 2007; Esperanza et al., 2007; Steiner, 2007). Agricultural waste is derived into biochar, whereby the thermochemistry during pyrolysis results in the transformation of a carbon-containing compound. As the $\mathrm{H}$ and $\mathrm{O}$ elements are exhausted (Kucukbayrak and Kadioglu, 1989), the proportion of the aromatic carbon compound is higher than that for primordial matter (Baldock and Smernik, 2002), thus providing larger structures that are difficult to be decomposed chemically and resistant to biological decomposition (Zimmerman, 2010), and so the biochar is more significant for the use of carbon sequestration (Lehmann et $a l ., 2006)$. Sorghum distillery residue (SDR) is declared as one of the general industrial wastes according to agricultural statistics from the Environmental Protection Administration, Executive Yuan, Taiwan (2012). Due to its high nutrient content, it rots and deteriorates without timely disposal, is easy to severely pollute an ambient

\footnotetext{
Department of Horticulture, College of Agriculture, National Chiayi University, Chiayi, Taiwan, ROC.

2 Graduate Institute of Wood Based Materials and Design, College of Agriculture, National Chiayi University, Chiayi, Taiwan, ROC.

Laboratory of Environment Functional Materials, Department of Wood Based Materials and Design, College of Agriculture, National Chiayi University, Chiayi, Taiwan, ROC.

* Corresponding author (E-mail: alexhlin@mail.ncyu.edu.tw)
}

environment, and breeds bacteria, e.g. Aflatoxin, generating harmful toxins (Bustamante et al., 2007). Therefore, it would be quite useful if distillers' grains could be fermented to prepare biochar (Lin and Huang, 2016; Kuo et al., 2018), especially in the environmental carbon cycle.

Biochar carbonization technology has become quite mature in recent years. Different feedstocks and different preparation conditions, such as pyrolysis temperature, heating rate, and duration time, influence the yield, physical and chemical properties, and composition of biochar (Jindo et al., 2014; Lin and Huang, 2016; Kuo et al., 2018). Biochar also influences the physicochemical and biological properties of soil, as it can enhance or conserve soil fertility (Steiner, 2007), such as adjusting the soil pH (Topoliantz et al., 2005; Van Zwieten et al., 2010), increasing the cation exchange capacity (CEC) (Cheng et al., 2008; Liang et al., 2006), and even increasing the crop yield (Lehmann and Joseph, 2009; Paradelo et al., 2013). Gaskin et al. (2008) indicate that biochar prepared by low temperature pyrolysis has a significantly higher CEC, and biochar is a potential agricultural nutrient source, because it may increase the major elements for plants, such as nitrogen, phosphor, and potassium, and it may enhance carbon sequestration. Kuo et al. (2018) note that the biochar prepares from SDR at pyrolysis temperature of $450^{\circ} \mathrm{C}$ by $60 \mathrm{~min}$ of duration time and uses in a plug seedling culture medium contributes to seedling growth; the seedling index and the CEC in seedlings period are higher than the control group (a culture medium for peat with perlite), and the vegetable plug seedlings with a higher 
seedling index has a higher CEC value. Therefore, the biochar derived of SDR can increase the utility value and is effective on "carbon fixation", thus reducing $\mathrm{CO}_{2}$ emissions and solving environmental and soil problems (Lehmann et al., 2006; Steiner, 2007).

Carbonization temperature and duration time can influence the pore characteristics of biochar (Jindo et al., 2014; Lin et al., 2014; Kuo et al., 2018). Therefore, this study used different pyrolysis temperatures and duration times to derive SDR into sorghum distillery residue biochar (SDRBC), the physicochemical properties, fertility index and the effect on plug seedling quality were investigated. First, SDRBC and peat were mixed uniformly as per different volume ratios to form culture media containing SDRBC, the physicochemical properties were measured. Second, the general cultivation management of plug seedling was used, and the fertility index, including total nitrogen, effective phosphorus, exchangeable potassium, and CEC were assayed. The effect of various SDRBCs on plug seedling quality was then evaluated by the seedling index.

\section{MATERIALS AND METHODS}

\section{Feedstock specimen and test materials}

Sorghum distillery residue (SDR) was as the feedstock from K Liquor Inc., and pulverized to 5-10 mesh for future use. The basic properties of sorghum distillery residue biochar (SDRBC) were refer to (Kuo et al., 2018). Peat was Klasmann select peat, produced by the German Klasmann-Deilmann company, and its $\mathrm{pH}$ was 5.5-6.5, which was used as the main of cultural medium to be mixed with SDRBC. Perlite was perlite \#4, produced by Taiwan Nan Hai Vermiculite Industrial Co. Ltd., which was over 55.16\% with 5-10 mesh. The volume ratio of peat and perlite was about 15:85 (v/v\%) (Lin et al., 2010).

The nutrient solution "New Baide Fertilizer No. 6" (Professional, J. R. Peters Inc., USA), which contained the ratio of nitrogen phosphorous and potassium being 20:10:20. The plug was PE material circular tray with a number of 128 grids. The size of the tray is length $\times$ width $\times$ height $=60 \times 30 \times 3 \mathrm{~cm}$. The unit plug volume is $15.2\left(\mathrm{~cm}^{3}\right)$. Brassica oleracea (Cabbage), bought from the TAKII Seed Co., Ltd., was as the vegetable for plug seedling testing.

\section{Test methods}

\section{Preparation of SDRBC}

The feedstock, sorghum distillery residue (SDR), was absolutely dried. About $20 \mathrm{~g}$ specimen was put in the crucible, and placed in a vertical high temperature activation furnace (Chi-How Heating Co., Ltd.). After vacuum pumping, the inside furnace was free of oxygen, carbonization was set at 300,450 , and $600^{\circ} \mathrm{C}$ of carbonization temperatures, and the heating rate was $10^{\circ} \mathrm{C} / \mathrm{min}$. The nitrogen was put into the carbonization process, the gas flow was $200 \mathrm{~mL} / \mathrm{min}$, and the temperature was maintained for 0 and $60 \mathrm{~min}$. Finally, the nitrogen was flowed into the furnace for cooling to room temperature and then SDRBC was taken out and weighed. The SDRBCs were coded carbonization temperature-duration time, such as T450-0 was $450^{\circ} \mathrm{C}$ of carbonization temperature with 0 min of duration time.

\section{Basic properties of SDRBC}

SDRBC yield was calculated by yield $(\%)=$ (oven dry weight of SDRBC/oven dry weight of SDR) $\times 100$. $\mathrm{pH}$ value was measured by $\mathrm{pH}$ meter (SUNTEX TS-1) after the solution of various biochars with distilled water mixed in ratio of 1:5 (v/v\%) was kept still for $2 \mathrm{~h}$. Iodine value was evaluated according to JIS K 1474 (1991). The electrical conductivity (EC) of each SDRBC was same as the acid-alkali mixed solution ratio, measured by pen type EC meter (SUNTEX SC-120). The cation exchange capacity (CEC) was investigated and the detail experimental steps of CEC refer to (Hendershot and Duquette, 1986).

The elements analysis of SDRBC was measured by an elements analyzer (Elementar vario EL), according to the NIEA R409.21C standard. For the Fourier transform infrared spectrum (FTIR) analysis, various SDRBCs were pulverized, sieved through 20-40 mesh screen and completely dried in oven. The infrared spectrum was analyzed by Fourier transform infrared spectroscopy (Bio-Rad FTS-40), the detector was the deterated triglycine sulphate (DTGS), the resolution was $4 \mathrm{~cm}^{-1}$, the number of scans was 64 , the spectrum scanning area was $400-4000 \mathrm{~cm}^{-1}$, in order to analyze the surface functional group of each SDRBC.

\section{Blending of culture media with SDRBC}

For preparation of culture media containing SDRBC, various derived SDRBCs were blended with peat in several volume ratios of 15:85, 30:70, and 50:50 (v/v\%) (Lin et al., 2010). The control group used commercially available peat and perlite. The culture media containing SDRBCs were coded carbonization temperature-duration time-volume ratio for SDRBC, such as T450-0-15 was $450^{\circ} \mathrm{C}$ of carbonization temperature with 0 min of duration time at $15 \%$ volume ratio for SDRBC.

\section{Physicochemical properties of culture media with $S D R B C$}

The physical properties of culture medium (Bragg and Chambers, 1988) for various culture media containing SDRBCs were investigated, and included air-filled porosity (AFP), container capacity (CC, also known as medium moisture capacity), total porosity (TP) and bulk density (BD). The detail experimental steps of above physical properties refer to (Kuo et al., 2018). In each seedling investigation, the culture media containing SDRBC of three plugs were taken, and measured by $\mathrm{pH}$ measuring method (the same as the measurement of SDRBC properties). The culture media containing SDRBC of another three plugs were taken for measuring EC value. CEC was investigated from the culture media containing SDRBC of the other three plugs. 
Fertility index of culture media with $S D R B C$

For total nitrogen assay, $0.5 \mathrm{~g}$ of each culture media containing SDRBC specimen was placed in the decomposing tube, mixed it with $7 \mathrm{~mL}$ concentrated sulfuric acid uniformly, kept still for at least $6 \mathrm{~h}$, heated under a low fire $\left(100^{\circ} \mathrm{C}\right)$ at a heating rate of $10^{\circ} \mathrm{C} / 30 \mathrm{~min}$ to $270^{\circ} \mathrm{C}$, and kept for $1 \mathrm{~h}$ to observe the dissolution of the specimen. The decomposing tube was taken out and cooled, when the specimen dissolved into a transparent state. After cooling, the decomposing liquid was poured into a $25 \mathrm{~mL}$ volumetric flask, quantified to $25 \mathrm{~mL}$, mixed uniformly, and filtered through a filter paper into a plastic bottle; $5 \mathrm{~mL}$ decomposing liquid and $5 \mathrm{~mL} 40 \% \mathrm{NaOH}$ were poured into the digestive tube, and the digestive tube was put in Kjeldahl distillation and nitrogen element titration apparatus (BUCHI Distillation Unit $\mathrm{K}-350)$ for distillation. The distilled liquid was mixed in the mixed liquor with $20 \mathrm{~mL}$ boric acid and titrated with $0.1 \mathrm{~N} \mathrm{HCl}$; the titer was then recorded and calculated by the following equation.

Nitrogen concentration $(\mathrm{mg} / \mathrm{kg})=\left[\left(\mathrm{V}_{1}-\mathrm{V}_{2}\right) \times 0.01 \times 14 \times\right.$

25] / (recovery rate $\left.\times W \mathrm{t} \times V_{\mathrm{s}}\right)$

Here, $\mathrm{V}_{1}$ : titration volume (mL) of nitrogenous standard; $\mathrm{V}_{2}$ : blank titration volume $(\mathrm{mL})$ of the sample solution; recovery rate $(\%)=\left[\left(\mathrm{V}_{1}-\right.\right.$ $\left.\left.\mathrm{V}_{2}\right) \times 0.01 \times 14 \times 1000\right] / 500 \mathrm{ppm} \times 1 \mathrm{~mL} ; W \mathrm{t}$ : specimen weight (g) for decomposition; $V_{\mathrm{s}}$ : volume $(\mathrm{mL})$ of the specimen solution for distillation

The phosphorus content assay first put $2.0 \mathrm{~g}$ of each culture medium in the plastic centrifuge tube, mixed it with $45 \mathrm{~mL} 0.5 \mathrm{M} \mathrm{NaHCO}_{3}$, shook for $30 \mathrm{~min}$ and filtered it through a filter paper, and collected the filtrate for future use. The effective phosphorus was analyzed by a spectrophotometer. The phosphorus standard curve was prepared before analysis; $8 \mathrm{~mL}$ vitamin $\mathrm{C}$ mixed liquor was extracted accurately by pipet and put in six $50 \mathrm{~mL}$ volumetric flasks and mixed with a little distilled water to observe whether the solution in the flask changes color, and made sure the volumetric flask and distilled water were free of contamination and color change. Next, the solution was mixed with 10 ppm 0,1 , 2, 3, 4, and $5 \mathrm{~mL}$ phosphoric acid standard diluent and shaken slowly. When the solution turns blue, the timing lasts for $30 \mathrm{~min}$, and it was quantified with distilled water to $50 \mathrm{~mL}$, the phosphorus contents were $0.0,0.2,0.4$, $0.6,0.8$, and $1.0 \mathrm{ppm}$. When the time was terminated, the spectrophotometer (CECIL, CE3041) was used for color comparison with wavelength $882 \mathrm{~nm}$. The absorbance value was recorded, and a standard curve $f(\mathrm{x})$ was made with the given phosphorus concentration. Afterwards, $8 \mathrm{~mL}$ vitamin $\mathrm{C}$ mixed liquor was extracted accurately by pipet, put in the $50 \mathrm{~mL}$ volumetric flask, and mixed with a little distilled water to observe whether the solution in the flask changed color, and to make sure the volumetric flask and distilled water were free of contamination and color change. An amount of filtrate was then put in the $50 \mathrm{~mL}$ volumetric flask, and after the solution turned blue under timing lasting for $30 \mathrm{~min}$, it was quantified with distilled water to $50 \mathrm{~mL}$. When the time was terminated, the spectrophotometer was used for color comparison, the absorbance value was recorded, and the concentration corresponding to the measured value was calculated by previous phosphorus concentration standard curve equation $f(\mathrm{x})$.

$f(\mathrm{x})=0.40177 \mathrm{x}+0.0103$ Where, $\mathrm{x}$ : value measured by spectrophotometer

Effective phosphorus content $(\mathrm{mg} / \mathrm{kg})=[f(\mathrm{x}) \times 50$ $\times 45] /[2 \times$ filtrate dosage $(\mathrm{mL})]$

For the exchangeable potassium content assay, $1 \mathrm{~g}$ of culture media containing SDRBC specimen was put in the plastic centrifuge tube, leached with $\mathrm{NH}_{4} \mathrm{OAC}(1 \mathrm{~N}$, $\mathrm{pH}$ 7.0) three times, and the volume of liquor applied each time was $30 \mathrm{~mL}$, shaken for $10 \mathrm{~min}$ (150 rpm), and centrifuged for $10 \mathrm{~min}(5000 \mathrm{rpm})$. The supernatant clarified liquor after centrifugation was collected and quantified to $1000 \mathrm{~mL}$, and the potassium ion content in the solution was measured by an atomic absorption spectrophotometer (AAnalyst 700, Perkin Elmer). The spectral wavelength for assay was $766.5 \mathrm{~nm}$.

\section{Plug seedling and biomass investigation}

The SDRBCs derived under different conditions, and were blended with commercially available peat in different volume ratios as plug culture media. Cabbage was used as the vegetable for the test, and the effects of various culture media containing SDRBC on the quality of cabbage plug seedling growth were investigated. Plug seedling was performed on December 19, 2017. The sowing and culturing of seedlings were performed in a greenhouse on the $5^{\text {th }}$ floor of the Department of Horticulture, National Chiayi University on December 20, 2017 until January 24, 2017, for a period lasting 5 weeks.

Aside from general cultivation management, the seedlings were irrigated with New Baide Fertilizer No. 6 at 20-10-20 dilution 1000 times on Day 7 and then irrigated with it diluted 500 times once every 7 days; Day 7 , Day 21, and Day 35 were the early, middle, and late period of seedling raising, respectively. Three grids of culture media were taken from the plug to assay the fertility index before the nutrient solution was applied. In the seedling period, the $\mathrm{pH}$ and EC values of the culture media were assayed on Day 3 and then assayed once every 7 days. The biomass assay was investigated weekly from Week 2 to Week 5 of the seedling period; each condition took 4 cabbage seedlings as one replication, and there were 3 replications.

The investigated items (Bilderback et al., 1982; Fonteno, 1990) were included: 1) Character, involving (a) stem length $(\mathrm{cm})$ : length of cabbage seedling from the culture soil to the stem tip growing point; (b) stem diameter (mm): diameter of stem between the cabbage seedling stems base and the top of cotyledon; 2) Mass, including (a) fresh weight of whole plant: the whole cabbage seedling (including root system) was cleaned; (b) fresh weight of above-ground part: the stem base was cut off the cabbage seedling, the surface moisture was 
sucked up by gauze; (c) fresh weight of underground part: the underground root system was cleaned of culture soil. The surface moisture of whole cabbage seedling, above-ground part and underground part was individually sucked up by gauze, and the mass was weighed; (d) dry weight of whole plant: the whole cabbage seedling (including root system) was placed in the kraft bag, dried in a $70^{\circ} \mathrm{C}$ oven for $48 \mathrm{~h}$, and the mass was weighed; 3 ) the investigation of seedling index, two seedling indexes were used to evaluate the growth quality of cabbage seedlings. Seedling index I = (stem diameter/stem length) $\times$ dry weight of whole cabbage seedling; Seedling index II = [(stem diameter/stem length) + (fresh weight of underground part/fresh weight of above-ground part)] $\times$ dry weight of whole cabbage seedling.

\section{Statistical analysis}

The results were represented by a mean (standard deviation), and were statistically analyzed based on Duncan's multiple range tests at $5 \%$ significant level analysis, using the Statistical Package for Social Science (SPSS) software.

\section{RESULTS AND DISCUSSION}

\section{Basic properties of SDRBC}

The yield of various SDRBCs was 31.31-53.67\% (Table 1), which decreased as the carbonization temperature increased. Because the feedstock was carbonized, the volatile matter and tar dissipate, and the gasification of carbon increased (Walker and Almagro, 1995; Teng and $\mathrm{Hsu}, 1999)$. The SDRBCs yield of $60 \mathrm{~min}$ duration was $31.31-51.26 \%$, for without duration (0 min) time it was $32.70-53.67 \%$. The yield of 60 min duration clearly decreased. Gheorghe et al. (2009) indicate that the yield decreases as the duration time is extended. The $\mathrm{pH}$ value of SDRBC under different preparation conditions was 7.23-9.50 and was weakly alkaline or alkaline, and the $\mathrm{pH}$ of SDRBCs increased with the increase of carbonization temperature. The concentration of inorganic elements decreases relatively after high-tempera- ture treatment of the feedstock (Novak et al., 2009). It is suggested that when the soil is acidified, the weakly alkaline or alkaline biochar can adjust the $\mathrm{pH}$ of acid soil. The rootage development of the plant is promoted and the plant yield is also increased (Neary et al., 1999; Gundale and Deluca, 2006; Joseph et al., 2010). The iodine value of SDRBC was 126.90-372.24 (mg/g). High temperature pyrolysis usually has a higher iodine index than low temperature pyrolysis, meaning high temperature pyrolysis has more pores, which is coincident with previous findings (Gaskin et al., 2008; Lin et al., 2010; Peng and Lin, 2015; Kuo et al., 2018). The EC value decreased as the temperature increased, there was a higher EC value when the carbonization temperature was $300^{\circ} \mathrm{C}$, the $\mathrm{CEC}$ was a maximum $65.93 \mathrm{cmol} / \mathrm{kg}$ in low temperature carbonization, and the CEC without duration (0 min) was higher than that with duration (60 min).

The C element of SDRBC was 62.05-74.13\%, which increased relatively with carbonization temperature. Carrott P. and M. Carrott (2007) present that the lignin has high $\mathrm{C}$ content and is a kind of complex organic polymer and is difficult to be decomposed. It has weight losses in a wide range of carbonization temperature, like $160-900^{\circ} \mathrm{C}$, whereas hemicellulose and cellulose have weight losses within $220-315$ and $315-400^{\circ} \mathrm{C}$, respectively (Haiping et al., 2007). Therefore, the materials are ignited at high carbonization temperature, the lignin that is difficult to be decomposed remains, the $\mathrm{C}$ element content increases relatively, and aromatic graphitization is relatively complete (Reed and Williams, 2004). The contents of $\mathrm{H}$ and $\mathrm{O}$ elements decreased relatively as the pyrolysis temperature increased. It indicates that the oxygen deficient pyrolysis process in the carbonization furnace is accompanied by the formation of multiring hydrocarbon (Peng and Lin, 2015). The content of $\mathrm{N}$ element in various biochars was $4.69-6.82 \%$; in terms of $\mathrm{S}$ element, the organic $\mathrm{S}$ pyrolysis temperature is higher than $400^{\circ} \mathrm{C}$ (Kundsen et al., 1982; Kucukbayrak and Kadiog lu, 1989). In terms of N/C, H/C and $\mathrm{O} / \mathrm{C}$ of various SDRBCs, N/C was $0.06-0.11, \mathrm{H} / \mathrm{C}$ was $0.03-0.08$

Table 1. Yield, $\mathrm{pH}$ value, iodine value, EC value and $\mathrm{CEC}$ of SDRBC ${ }^{1)}$ derived with different

\begin{tabular}{lccccc}
\hline \multicolumn{1}{c}{ Specimen ${ }^{2)}$} & Yield (\%) & pH value & $\begin{array}{c}\text { Iodine value } \\
(\mathrm{mg} / \mathrm{g})\end{array}$ & $\begin{array}{c}\mathrm{EC} \mathrm{value}^{3)} \\
(\mathrm{dS} / \mathrm{m})\end{array}$ & $\begin{array}{c}\mathrm{CEC}^{4)} \\
(\mathrm{cmol} / \mathrm{kg})\end{array}$ \\
\hline T300-0 & $53.67(0.97)^{5)}$ & $7.23(0.02)$ & $126.90(21.98)^{\mathrm{Aa} 6)}$ & $0.49(0.01)^{\mathrm{Ab}}$ & $65.93(2.35)^{\mathrm{Bc}}$ \\
T300-60 & $51.26(0.92)$ & $7.58(0.02)$ & $152.28(40.79)^{\mathrm{Ax}}$ & $0.68(0.05)^{\mathrm{Bz}}$ & $45.39(4.46)^{\mathrm{Ay}}$ \\
\hline T450-0 & $36.35(0.29)$ & $8.85(0.02)$ & $173.43(07.33)^{\mathrm{Ab}}$ & $0.50(0.06)^{\mathrm{Bc}}$ & $43.21(0.45)^{\mathrm{Bb}}$ \\
T450-60 & $34.33(0.36)$ & $9.24(0.04)$ & $279.18(12.70)^{\mathrm{By}}$ & $0.45(0.01)^{\mathrm{Ay}}$ & $31.40(2.41)^{\mathrm{Ax}}$ \\
\hline T600-0 & $32.70(0.66)$ & $9.50(0.02)$ & $325.71(07.33)^{\mathrm{Ac}}$ & $0.31(0.08)^{\mathrm{Aa}}$ & $30.63(1.57)^{\mathrm{Aa}}$ \\
T600-60 & $31.31(0.60)$ & $9.50(0.02)$ & $372.24(19.38)^{\mathrm{Bz}}$ & $0.37(0.01)^{\mathrm{Bx}}$ & $30.57(1.27)^{\mathrm{Ax}}$ \\
\hline
\end{tabular}

${ }^{1)}$ SDRBC: Sorghum distillery residue biochar

2) Carbonization temperature-duration time

${ }^{3)}$ EC: Electrical conductivity

4) CEC: Cation exchange capacity

${ }^{5)}$ Mean (standard deviation)

${ }^{6}$ Mean (standard deviation) with the different large alphabets ABC for the specimen at the same carbonization temperature with different duration time, with the different small alphabets abc for the specimen at different carbonization temperature with duration time at $0 \mathrm{~min}$, and xyz for the specimen at different carbonization temperature with duration time at $60 \mathrm{~min}$ is significantly different $(\rho<0.05)$ by Duncan's multiple range tests 
and $\mathrm{O} / \mathrm{C}$ was $0.26-0.45$ (Table 2 ). The nutrient preserving capability can be estimated from N/C (Ghani et al., 2013), and a larger O/C ratio represents higher hydrophilicity and polarity of biochar. The hydrophilicity and polarity decrease as carbonization temperature increases, and the nutrient preserving capability subsequently degrades (Xin et al. 2016). It is also suggested that the increase in aromatic structures further stabilizes the properties of SDRBC.

Table 2. N/C, H/C, O/C of SDRBC ${ }^{1)}$ derived with different condition

\begin{tabular}{lccc}
\hline Specimen $^{2)}$ & $\mathrm{N} / \mathrm{C}$ & $\mathrm{H} / \mathrm{C}$ & $\mathrm{O} / \mathrm{C}$ \\
\hline T300-0 & $0.08(0.03)^{3)}$ & $0.08(0.00)$ & $0.45(0.14)$ \\
T300-60 & $0.11(0.01)$ & $0.05(0.00)$ & $0.39(0.12)$ \\
\hline T450-0 & $0.08(0.01)$ & $0.05(0.00)$ & $0.40(0.08)$ \\
T450-60 & $0.07(0.05)$ & $0.04(0.00)$ & $0.35(0.06)$ \\
\hline T600-0 & $0.07(0.01)$ & $0.03(0.00)$ & $0.27(0.22)$ \\
T600-60 & $0.06(0.03)$ & $0.03(0.00)$ & $0.26(0.19)$ \\
\hline
\end{tabular}

${ }^{1)} \mathrm{N} / \mathrm{C}, \mathrm{H} / \mathrm{C}, \mathrm{O} / \mathrm{C}$ : the element of $\mathrm{C}$ (Carbon), $\mathrm{H}$ (Hydrogen), O

(Oxygen), and N (Nitrogen); SDRBC: See Table 1

2), 3) See Table $1^{2), 5)}$

\section{Properties and fertility index of culture media with SDRBC \\ FTIR}

The FTIR analysis was performed for T300-0, T30060, and $\mathrm{T} 450-0$. The $\mathrm{CH}$ and $\mathrm{CH}_{2}$ vibration peaks at $2850-3000 \mathrm{~cm}^{-1}$ and characteristic absorption peaks of the aromatic compound of lignin at 1510, 1453, and $1232 \mathrm{~cm}^{-1}$ (Yamada and Ono, 1999). According to the higher CEC (Table 1), the $\mathrm{C}-\mathrm{H}$ stretching vibration hydrophilic functional group was at about $2926 \mathrm{~cm}^{-1}$, the peak weakened gradually as the carbonization temperature increased, and the O/C (Table 2) of high carbonization temperature had lower hydrophilicity. The characteristic absorption peak of the aromatic compound of lignin was at $1103 \mathrm{~cm}^{-1}$, which strengthened gradually as the carbonization temperature increased. Haiping et al.
(2007) report that the lignin is a material that is difficult to be decomposed, and for the hemicellulose and cellulose, they have weight loss within 220-315 and 315$400^{\circ} \mathrm{C}$, respectively.

\section{$C E C$}

In terms of the CEC variations of various culture media on Days 7, 21, and 35 of the seedling period, the CEC of the peat was $60.31,44.58$, and $62.19 \mathrm{cmol} / \mathrm{kg}$, respectively; the CEC of the media containing SDRBC was $45.60-129.28 \mathrm{cmol} / \mathrm{kg}$; and the CECs of T300-0-15 and T300-60-15 on Day 7 of seedling were lower than peat, and thus there was no significant difference among them (Table 3). When the volume ratio of SDRBC addition was $15 \%$ on Day 7 of seedling, the CEC was 45.60 $81.09 \mathrm{cmol} / \mathrm{kg}$; the CEC was $75.36-107.09 \mathrm{cmol} / \mathrm{kg}$ when the SDRBC addition was 50\%, indicating the CEC increased with the volume ratio of SDRBC addition. In terms of carbonization temperature, the CEC of SDRBC decreased as the temperature increased, and the CEC of T450 was larger than T300. Joseph et al. (2010) state that biochar can provide an environment favorable for parasitism of fungi and microorganisms, increasing soil microbes, so as to increase the CEC of soil. According to the iodine value results (Table 1 ), the high carbonization temperature had a higher iodine value, but the SDRBC without duration time; therefore, had a larger CEC. In the middle (Day 21) and late (Day 35) period of seedling, the peat has the lowest CEC among various culture media, which may be because the SDRBC addition to the culture media contributes to the nutrient preserving capability of the soil.

\section{Total nitrogen}

Table 4 showed the change in the total nitrogen of various culture media on Days 7, 21, and 35 of the seedling period. The total nitrogen in the peat seedling period was $20.21,22.75$, and $17.35 \mathrm{~g} / \mathrm{kg}$, respectively; the total nitrogen in the media containing SDRBC was $25.74-84.83 \mathrm{~g} / \mathrm{kg}$; the total nitrogen in the media containing SDRBC was higher than that of peat, showing signifi-

Table 3. CEC change of cabbage plug seedlings in each culture medium

\begin{tabular}{lccc}
\hline \multirow{2}{*}{$\begin{array}{c}\text { Culture } \\
\text { medium }\end{array}{ }^{1)}$} & \multicolumn{3}{c}{ Seedling days (day) } \\
\cline { 2 - 4 } Peat & $60.31(1.41)^{\text {Aaxz })}$ & $44.58(1.71)^{\text {Aax }}$ & $62.19(3.27)^{\text {Aax }}$ \\
\hline T300-0-15 & $45.60(1.71)^{\mathrm{A}}$ & $82.37(2.17)^{\mathrm{B}}$ & $71.68(7.63)^{\mathrm{A}}$ \\
T300-60-15 & $50.72(3.48)^{\mathrm{A}}$ & $97.59(0.51)^{\mathrm{C}}$ & $69.89(1.58)^{\mathrm{A}}$ \\
\hline T300-0-50 & $83.24(3.59)^{\mathrm{b}}$ & $57.16(0.66)^{\mathrm{B}}$ & $65.20(2.40)^{\mathrm{a}}$ \\
T300-60-50 & $75.36(1.79)^{\mathrm{b}}$ & $74.38(3.30)^{\mathrm{C}}$ & $67.71(4.65)^{\mathrm{a}}$ \\
\hline T450-0-15 & $81.09(0.98)^{\mathrm{y}}$ & $54.33(0.95)^{\mathrm{y}}$ & $79.51(3.22)^{\mathrm{y}}$ \\
T450-0-50 & $107.09(9.85)^{\mathrm{z}}$ & $129.28(4.07)^{\mathrm{z}}$ & $127.09(0.65)^{\mathrm{z}}$ \\
\hline${ }^{1)}$ Carbonization temperature-duration time- volume ratio of SDRBC addition \\
2) Mean (standard deviation) with the different large alphabets ABC for the specimen T300- \\
0-15 and T300-60-15, with the different small alphabets abc for the specimen T300-0-50 \\
and T300-60-50, and xyz for the specimen T450-0-15 and T450-0-50 at different \\
carbonization temperature with duration time at 0 min is significantly different $(\rho<0.05)$ \\
by Duncan's multiple range tests
\end{tabular}


cant difference according to the analysis of Duncan's multiple range tests. The total nitrogen was 25-74$40.77 \mathrm{~g} / \mathrm{kg}$ when the volume ratio of SDRBC addition was $15 \%$, the total nitrogen was $59.73-84.83 \mathrm{~g} / \mathrm{kg}$ when the SDRBC addition was 50\%, indicating the total nitrogen increased with the increase of the volume ratio for SDRBC addition. On Days 7, 21, and 35 of seedling, the total nitrogen of various culture media was 20.21-80.27, $22.75-84.83$, and $17.73-64.58 \mathrm{~g} / \mathrm{kg}$, respectively, which might be because the cabbage seedlings required less nitrogen in the initial seedling period and the fertilization in the period slightly increased total nitrogen. The total nitrogen on Day 35 of seedling was lower than that on Day 21. It is perhaps because the nitrogen is absorbed by growing the plant or is lost through irrigation.

\section{Effective phosphorus content}

The effective phosphorus content of the peat in the seedling period was $267.71,113.28$, and $146.76 \mathrm{mg} / \mathrm{kg}$, respectively (Table 4). Except for T450-0-15 and T450-0-50, the effective phosphorus content in the media containing SDRBC was higher than that in peat, likely because the carbonization temperature $450^{\circ} \mathrm{C}$ had higher pH 8.85 (Table 1), and high pH typically forms calcium biphosphate $\left(\mathrm{Ca}\left(\mathrm{H}_{2} \mathrm{PO}_{4}\right)_{2}\right)$, degrading the effectiveness of phosphorus, and thus the effective phosphorus was lower than the other culture media (Helling et al., 1964). The effective phosphorus in the culture media containing SDRBC carbonized at lower temperature was higher than peat. This is because the main physical characteristics of biochar are a porous structure (Kuo et al., 2018) and a large specific surface area (Peng and Lin, 2015). This structure provides the refugia to soil microbes, so that they secrete enzyme to promote the degradation of organic matter and nutrient mineralization, and the culture medium enhances the effectiveness of macronutrients (Ip et al., 2008).

\section{Exchangeable potassium content}

The exchangeable potassium, also shown in Table 4 , in the peat seedling period was $13.36,6.69$, and 3.17 $\mathrm{cmol} / \mathrm{kg}$, respectively. The exchangeable potassium in the media containing SDRBC was $18.40-90.21 \mathrm{cmol} / \mathrm{kg}$, the exchangeable potassium in the media containing SDRBC was higher than peat; that with $15 \%$ SDRBC was $18.40-90.21 \mathrm{cmol} / \mathrm{kg}$; and that with $50 \%$ SDRBC was $49.75-161.80 \mathrm{cmol} / \mathrm{kg}$. Therefore, the exchangeable potassium increased with the volume ratio of SDRBC addition. The exchangeable potassium in various culture media on Day 7 of seedling was $13.36-161.80 \mathrm{cmol} / \mathrm{kg}$, and the exchangeable potassium in various culture media on Day 35 of seedling was $3.17-96.11 \mathrm{cmol} / \mathrm{kg}$. The exchangeable potassium in the culture media, except for T450-0-50, decreases as the number of seedling days increases, perhaps because the T450-0-50 has higher adsorbability, and the exchangeable potassium is unlikely to be absorbed by the plant or is unlikely to be

Table 4. Fertility index change of cabbage plug seedlings in each culture medium

\begin{tabular}{|c|c|c|c|c|}
\hline \multirow{2}{*}{ Fertility index } & \multirow{2}{*}{ Culture medium $^{1)}$} & \multicolumn{3}{|c|}{ Seedling days (day) } \\
\hline & & 7 & 21 & 35 \\
\hline \multirow{7}{*}{ Total nitrogen } & Peat & $20.21(0.31)^{\operatorname{Aax} 2)}$ & $22.75(1.41)^{\operatorname{Aax}}$ & $17.73(5.19)^{\operatorname{Aax}}$ \\
\hline & T300-0-15 & $35.93(1.49)^{\mathrm{B}}$ & $40.77(3.22)^{\mathrm{B}}$ & $25.74(0.53)^{\mathrm{B}}$ \\
\hline & T300-60-15 & $40.77(3.35)^{\mathrm{B}}$ & $40.51(2.43)^{\mathrm{B}}$ & $39.17(1.48)^{\mathrm{B}}$ \\
\hline & T300-0-50 & $68.51(1.61)^{\mathrm{b}}$ & $69.86(1.25)^{\mathrm{b}}$ & $59.73(17.09)^{\mathrm{b}}$ \\
\hline & T300-60-50 & $80.27(0.16)^{b}$ & $84.83(3.94)^{c}$ & $73.10(0.18)^{b}$ \\
\hline & $\mathrm{T} 450-0-15$ & $36.31(6.50)^{y}$ & $36.80(0.03)^{y}$ & $33.55(1.05)^{x}$ \\
\hline & $\mathrm{T} 450-0-50$ & $69.27(5.52)^{\mathrm{z}}$ & $76.20(3.38)^{\mathrm{z}}$ & $64.58(0.30)^{y}$ \\
\hline \multirow{7}{*}{ Available phosphorus } & Peat & $267.71(2.51)^{\operatorname{Aax}}$ & $113.28(6.95)^{\operatorname{Aax}}$ & $146.76(4.47)^{\operatorname{Aax}}$ \\
\hline & T300-0-15 & $446.33(13.14)^{\text {в }}$ & $213.71(16.39)^{\text {в }}$ & $253.99(3.50)^{\mathrm{C}}$ \\
\hline & T300-60-15 & $486.62(16.75)^{\mathrm{C}}$ & $422.50(2.12)^{\mathrm{C}}$ & $214.85(4.88)^{\text {в }}$ \\
\hline & T300-0-50 & $485.29(2.78)^{b}$ & $338.53(3.50)^{\mathrm{b}}$ & $370.87(32.96)^{\mathrm{b}}$ \\
\hline & Т300-60-50 & $619.38(15.31)^{c}$ & $505.91(5.26)^{c}$ & $474.70(4.25)^{\mathrm{c}}$ \\
\hline & T450-0-15 & $215.98(6.86)^{x}$ & $176.83(9.25)^{\mathrm{y}}$ & $105.34\left(0.80^{x}\right.$ \\
\hline & $\mathrm{T} 450-0-50$ & $213.71(1.39)^{\mathrm{x}}$ & $183.64(19.67)^{\text {y }}$ & $215.98(4.25)^{\mathrm{y}}$ \\
\hline \multirow{7}{*}{ Exchangeable potassium } & Peat & $13.36(0.27)^{\operatorname{Aax}}$ & $6.69(0.63)^{\operatorname{Aax}}$ & $3.17(0.02)^{\text {Aax }}$ \\
\hline & T300-0-15 & $31.05(0.47)^{\mathrm{B}}$ & $45.87(0.62)^{\mathrm{B}}$ & $18.40(0.92)^{\mathrm{B}}$ \\
\hline & T300-60-15 & $90.21(5.44)^{\mathrm{C}}$ & $9.93(5.04)^{\mathrm{C}}$ & $40.87(1.55)^{\mathrm{C}}$ \\
\hline & T300-0-50 & $61.58(0.11)^{\mathrm{b}}$ & $79.87(7.08)^{b}$ & $49.75(0.48)^{\mathrm{b}}$ \\
\hline & T300-60-50 & $161.80(0.83)^{c}$ & $141.601(5.34)^{c}$ & $87.32(0.92)^{c}$ \\
\hline & $\mathrm{T} 450-0-15$ & $39.16(0.19)^{y}$ & $51.32(3.22)^{\mathrm{y}}$ & $27.37(1.91)^{\mathrm{y}}$ \\
\hline & $\mathrm{T} 450-0-50$ & $60.70(1.98)^{z}$ & $76.35(5.47)^{z}$ & $96.11(0.44)^{2}$ \\
\hline
\end{tabular}

${ }^{1), 2)}$ See Table $3^{1 \text {, 2) }}$ 
lost by irrigation.

\section{Biomass investigation of culture media with SDRBC}

Character and mass

On Day 14 of seedling, the cabbage seedling stem length of peat was $25.56 \mathrm{~mm}$, and the stem diameter was $1.22 \mathrm{~mm}$, which were both maximum values (Table 5). The leaf area of T300-60-15 was a maximum $2.13 \mathrm{~cm}^{2}$, and there was no obvious trend detected on Day 14 of seedling. On Day 21 of seedling, T300-60-15 and T45060-15 had larger leaf areas, which were 11.10 and $11.20 \mathrm{~cm}^{2}$, respectively. There was a significant difference to peat according to Duncan's analysis, and that with $15 \%$ SDRBC was larger than that with $50 \%$. On Day 35, T450-0-15 had the maximum stem length and stem diameter, which were 34.94 and $1.72 \mathrm{~mm}$, respectively. The leaf areas of the media containing SDRBC other than T450-0-50 were larger than peat, which were $23.44-27.36$ and $20.88 \mathrm{~cm}^{2}$, respectively. The total nitro-

Table 5. Character and mass change of cabbage plug seedlings in each culture medium

\begin{tabular}{|c|c|c|c|c|c|c|}
\hline \multirow{3}{*}{ Culture medium $^{1)}$} & \multicolumn{6}{|c|}{ Seedling days (day) } \\
\hline & \multicolumn{3}{|c|}{14} & \multicolumn{3}{|c|}{21} \\
\hline & $\begin{array}{l}\text { Stem lengh } \\
\text { (mm) }\end{array}$ & $\begin{array}{c}\text { Stem diameter } \\
(\mathrm{mm})\end{array}$ & $\begin{array}{c}\text { Leaf area } \\
\left(\mathrm{cm}^{2}\right)\end{array}$ & $\begin{array}{l}\text { Stem lengh } \\
(\mathrm{mm})\end{array}$ & $\begin{array}{c}\text { Stem diameter } \\
(\mathrm{mm})\end{array}$ & $\begin{array}{c}\text { Leaf area } \\
\left(\mathrm{cm}^{2}\right)\end{array}$ \\
\hline Peat & $25.56(2.66)^{\mathrm{Bby} 1)}$ & $1.22(0.03)^{\text {Bby2) }}$ & $1.63(0.14)^{\text {Aby }}$ & $33.82(3.83)^{\text {Aby }}$ & $1.49(0.10)^{\mathrm{Abx}}$ & $9.23(1.43)^{\mathrm{ABbcy}}$ \\
\hline T300-0-15 & $21.94(1.47)^{\mathrm{AB}}$ & $1.01(0.05)^{\mathrm{A}}$ & $1.69(0.54)^{\mathrm{A}}$ & $31.26(2.88)^{\mathrm{A}}$ & $1.48(0.17)^{\mathrm{A}}$ & $9.72(1.97)^{\mathrm{BC}}$ \\
\hline T300-60-15 & $23.09(1.98)^{\mathrm{A}}$ & $1.12(0.03)^{\mathrm{A}}$ & $2.13(0.31)^{\mathrm{B}}$ & $30.61(0.87)^{\mathrm{A}}$ & $1.50(0.02)^{\mathrm{A}}$ & $11.10(0.97)^{\mathrm{C}}$ \\
\hline Т $300-0-50$ & $14.87(2.36)^{\mathrm{a}}$ & $0.90(0.08)^{\mathrm{a}}$ & $0.40(0.12)^{\mathrm{a}}$ & $23.59(0.65)^{\mathrm{a}}$ & $1.23(0.08)^{\mathrm{a}}$ & $3.57(1.54)^{\mathrm{a}}$ \\
\hline T300-60-50 & $19.94(1.03)^{b}$ & $0.96(0.06)^{\mathrm{a}}$ & $1.46(0.20)^{\mathrm{b}}$ & $25.07(1.61)^{\mathrm{a}}$ & $1.42(0.00)^{\mathrm{b}}$ & $7.27(1.15)^{\mathrm{ab}}$ \\
\hline $\mathrm{T} 450-0-15$ & $21.96(0.70)^{y}$ & $1.16(0.08)^{y}$ & $2.03(0.24)^{y}$ & $31.92(2.17)^{y}$ & $1.52(0.03)^{x}$ & $11.20(1.01)^{\mathrm{z}}$ \\
\hline $\mathrm{T} 450-0-50$ & $16.91(2.73)^{x}$ & $0.97(0.05)^{x}$ & $0.96(0.48)^{x}$ & $23.95(1.94)^{x}$ & $1.36(0.06)^{x}$ & $6.05(1.86)^{x y}$ \\
\hline Culture medium $^{1)}$ & \multicolumn{3}{|c|}{28} & \multicolumn{3}{|c|}{35} \\
\hline Peat & $34.71(3.15)^{\text {Aby }}$ & $1.60(0.09)^{\text {Aby }}$ & $15.84(1.42)^{\mathrm{ABby}}$ & $32.24(4.55)^{\text {Aaxy }}$ & $1.63(0.07)^{\text {Aay }}$ & $20.88(2.79)^{\operatorname{Aax}}$ \\
\hline $\mathrm{T} 300-0-15$ & $32.50(1.44)^{\mathrm{A}}$ & $1.72(0.13)^{\mathrm{A}}$ & $17.71(1.82)^{\text {в }}$ & $30.25(0.73)^{\mathrm{A}}$ & $1.66(0.07)^{\mathrm{A}}$ & $25.59(1.54)^{\mathrm{BC}}$ \\
\hline T300-60-15 & $34.49(1.63)^{\mathrm{A}}$ & $1.56(0.02)^{\mathrm{A}}$ & $13.19(2.27)^{\mathrm{A}}$ & $32.48(1.69)^{\mathrm{A}}$ & $1.65(0.05)^{\mathrm{A}}$ & $27.36(2.00)^{\mathrm{C}}$ \\
\hline T300-0-50 & $25.86(2.26)^{\mathrm{a}}$ & $1.43(0.03)^{\mathrm{a}}$ & $7.15(0.45)^{\mathrm{a}}$ & $31.45(3.07)^{\mathrm{a}}$ & $1.55(0.09)^{\mathrm{a}}$ & $23.44(3.50)^{\mathrm{b}}$ \\
\hline T300-60-50 & $28.32(1.97)^{\mathrm{ab}}$ & $1.54(0.07)^{\mathrm{ab}}$ & $13.96(1.32)^{b}$ & $28.32(4.91)^{\mathrm{a}}$ & $1.58(0.09)^{\mathrm{a}}$ & $24.98(1.11)^{b}$ \\
\hline $\mathrm{T} 450-0-15$ & $33.89(2.13)^{y}$ & $1.60(0.02)^{y}$ & $11.83(1.88)^{\mathrm{x}}$ & $34.94(1.93)^{y}$ & $1.72(0.17)^{\mathrm{y}}$ & $23.57(8.97)^{y}$ \\
\hline T450-0-50 & $27.60(2.53)^{x}$ & $1.55(0.06)^{\mathrm{x}}$ & $14.47(1.64)^{y}$ & $25.99(1.54)^{x}$ & $1.41(0.05)^{\mathrm{x}}$ & $18.52(0.61)^{\mathrm{x}}$ \\
\hline
\end{tabular}

1),2) See Table $3^{1), 2)}$

Table 6. Seeding index (I) and (II) ${ }^{1)}$ on the seedling period of cabbage plug seedlings in each culture medium

\begin{tabular}{|c|c|c|c|c|c|}
\hline \multirow{2}{*}{ Seeding index } & \multirow{2}{*}{ Culture medium $^{2)}$} & \multicolumn{4}{|c|}{ Seedling days (day) } \\
\hline & & 14 & 21 & 28 & 35 \\
\hline \multirow{7}{*}{ (I) } & Peat & $0.0009(0.0000)$ & $0.0018(0.0001)$ & $0.0041(0.0007)$ & $0.0072(0.0002)^{\mathrm{ABay} 3)}$ \\
\hline & T300-0-15 & $0.0008(0.0002)$ & $0.0018(0.0004)$ & $0.0055(0.0009)$ & $0.0083(0.0006)^{\mathrm{B}}$ \\
\hline & T300-60-15 & $0.0010(0.0003)$ & $0.0013(0.0007)$ & $0.0036(0.0001)$ & $0.0080(0.0006)^{\mathrm{A}}$ \\
\hline & T300-0-50 & $0.0007(0.0001)$ & $0.0024(0.0002)$ & $0.0024(0.0005)$ & $0.0060(0.00011)^{\mathrm{a}}$ \\
\hline & T300-60-50 & $0.0009(0.0001)$ & $0.0019(0.0008)$ & $0.0040(0.0007)$ & $0.0076(0.0013)^{\mathrm{a}}$ \\
\hline & T450-0-15 & $0.0010(0.0002)$ & $0.0023(0.0006)$ & $0.0041(0.0006)$ & $0.0082(0.0015)^{y}$ \\
\hline & T450-0-50 & $0.0009(0.0004)$ & $0.0021(0.0004)$ & $0.0045(0.0004)$ & $0.0057(0.0003)^{\mathrm{x}}$ \\
\hline \multirow{7}{*}{ (II) } & Peat & $0.0082(0.0030)$ & $0.0095(0.0026)$ & $0.0287(0.0051)$ & $0.0490(0.0068)^{\text {Aay }}$ \\
\hline & T300-0-15 & $0.0080(0.0021)$ & $0.0101(0.0027)$ & $0.0351(0.0036)$ & $0.0726(0.0061)^{\text {в }}$ \\
\hline & Т300-60-15 & $0.0076(0.0019)$ & $0.0151(0.0012)$ & $0.0303(0.0096)$ & $0.0681(0.0064)^{\mathrm{B}}$ \\
\hline & T300-0-50 & $0.0049(0.0016)$ & $0.0060(0.0025)$ & $0.0151(0.0087)$ & $0.0483(0.0088)^{\mathrm{a}}$ \\
\hline & T300-60-50 & $0.0083(0.0025)$ & $0.0095(0.0032)$ & $0.0238(0.0056)$ & $0.0406(0.0026)^{\mathrm{a}}$ \\
\hline & T450-0-15 & $0.0086(0.0022)$ & $0.0120(0.0024)$ & $0.0321(0.0052)$ & $0.0516(0.0047)^{y}$ \\
\hline & T450-0-50 & $0.0057(0.0028)$ & $0.0081(0.0037)$ & $0.0217(0.0049)$ & $0.0351(0.0026)^{x}$ \\
\hline
\end{tabular}

${ }^{1)}$ Seedling index I = (stem diameter/stem length $) \times$ dry weight of whole cabbage seedling; Seedling index II = [(stem diameter/stem length) + (fresh weight of underground part/fresh weight of above-ground part)] $\times$ dry weight of whole cabbage seedling

2), 3) See Table $3^{1,2)}$ 
gen in the media containing SDRBC was higher than peat (Table 4). It might explain that the cabbage plug seedling leaf area is larger than the peat one.

\section{Plug seedling}

The seedling index (I) of various culture media on Day 14 of seedling period was 0.0009, 0.0008, 0.0010, $0.0007,0.0009,0.00010$, and 0.0009, respectively (Table $6)$. On Day 21 of seedling, the seedling index (I) of the media containing 50\% SDRBC was 0.0019-0.0024, or higher than $0.0013-0.0023$ of that with $15 \%$. The media containing 50\% SDRBC had a higher fertility index (Table 4), and the seedling index (I) calculated disregarding the cabbage root growth state was higher than the seedling index (II) of others. On Day 35, the seedling index (I) of the media containing 15\% SDRBC was $0.0080-0.0083$, or higher than $0.0057-0.0076$ of that with $50 \%$ and higher than 0.0072 of peat. In conclusion, T300-0-15 had the maximum 0.0083. As the number of seedling days increased, on Day 21 of seedling, the seedling index (II) of the media containing 15\% SDRBC was 0.0101-0.0151, or higher than $0.0060-0.0095$ of that with $50 \%$ and higher than 0.0095 of peat. T450-0-15 therefore had the maximum seedling index 0.0151. Day 21 and Day 28 of seedling had the same trend. On Day 35 of seedling, the seedling index (II) 0.0516-0.0726 of the culture media containing 15\% SDRBC was higher than 0.0351-0.0483 of that with 50\%, and higher than 0.0490 of peat.

In terms of the carbonization temperature of SDRBC, T450 has a higher iodine value than T300 (Table 1), which may because the greater number of pores and specific surface provide an environment for parasitism of microorganisms in the soil, and then the CEC of soil increases (Table 3). In terms of SDRBC T300 duration $60 \mathrm{~min}$ and no duration time (0 min), the CEC of T300-0 is 65.93, and that of T300-60 is 45.39, showing a significant difference (Table 3 ). In terms of the fertility index in the seedling period, they are significant differences only in exchangeable potassium (Table 4). There is no significant difference between the seedling indix (I) and (II), which are 0.0726 and 0.0681 (Table 6), meaning the duration time has no significant effect on cabbage plug seedling. In terms of energy savings, the SDRBC at low carbonization temperature and without duration time has application potential compared with that with duration time.

\section{CONCLUSION}

SDR was used to derive SDRBC at different carbonization temperatures for duration times of 0 and $60 \mathrm{~min}$. The effect of the culture media containing SDRBC on the quality of cabbage plug seedling was investigated. The $\mathrm{pH}$ value of SDRBC increased with carbonization temperature; EC value decreased as the carbonization temperature increased; and CEC without duration time was higher than that with duration time. The $\mathrm{C}$ element of SDRBC increased relatively as the carbonization temperature increased, and a small O/C had weaker hydro- philicity and polarity. The physical properties of the culture media containing SDRBC were able to meet the requirements for general perfect medium, but there were no significant difference among different media. The $\mathrm{pH}$ of chemical properties was 5.64-6.32, and the EC value was $0.30-0.50 \mathrm{dS} / \mathrm{m}$. According to the fertility index of culture media containing SDRBC in the seedling period, as the volume ratio of SDRBC addition increased, the fertility index increased, including the CEC, total nitrogen, effective phosphorus and exchangeable potassium contents, which were higher than the peat (control group). Moreover, T300-0-15 had the highest seedling indices (I) and (II) among the culture media containing SDRBC, which was significantly different from the control group. It is indicated that the culture media containing 15\% SDRBC prepared at carbonization temperature of $300^{\circ} \mathrm{C}$ without duration time leads to better seedling growth quality in plug seedling. In conclusion, from the objective of promoting soil to release nutrients and enhancing growth quality, energy savings, carbon reduction, and carbon sequestration, the blending SDRBC in plug seedling looks to have significant development potential in the future.

\section{ACKNOWLEDGEMENTS}

The authors are grateful to the K Liquor Inc., Taiwan for providing the experimental feedstock, sorghum distillery residue.

\section{AUTHOR CONTRIBUTION}

Wei-Ru KUO performed the experiments and analyzed the data with the statistical analysis. Nian-Chia YEH assisted the experiments and analyzed the data. Noboru FUJIMOTO participated in the design of the study and supervised the works. Han Chien LIN designed this study and wrote the paper. The authors assisted in editing of the manuscript and approved the final version.

\section{REFERENCES}

Agricultural statistics 2012 Council of Agriculture, Executive Yuan, Taiwan, ROC

Baldock, J. A. and R. J. Smernik 2002 Chemical composition and bioavailability of thermally, altered Pinus resinosa Red Pine wood. Organic Geochemistry, 33: 1093-1109

Bustamante, M. A., M. D. Pérez-Murcia, C. Paredes, R. Moral, A. Pérez-Espinosa and J. Moreno-Caselles 2007 Short-term carbon and nitrogen mineralization in soil amended with winery and distillery organic wastes. Bioresourse Technology, 98(17): 3269-3277

Bilderback, T. E., W. C. Fonteno and D. R. Johnson 1982 Physical properties of media composed of peanut hulls, pine bark, and peat moss and their effects on Azalea growth. Journal of the American Society for Horticultural Science, 107(3): 522-525

Bragg, N. C. and B. J. Chambers 1988 Interpretation and advisory applications of compost air-filled porosity (AFP) measurements. Acta Horticulturae, 221: 35-44

Carrott P. J. M. and M. M. L. R. Carrott 2007 Lignin-from natural adsorbent to activated carbon: A review. Bioresource Technology, 98: 2301-2312 
Cheng, C. H., J. Lehmann and M. H. Engelhard 2008 Natural oxidation of black carbon in soils: Changes in molecular form and surface charge along a climosequence. Geochimica et Cosmochimica Acta, 72(6): 1598-1610

Esperanza R., P. César, S. Nicola, N. Rogelio and P. Alfredo 2007 Humic acid-like fractions in raw and vermicomposted winery and distillery wastes. Geoderma, 139(3): 397-406

Fonteno, W. C. 1990 Know your media. Growertalks on plugs. Growertalks magazine. pp. 84-92

Gaskin, J. W., C. Steiner, K. Harris, K. C. Das and B. Bibens (2008) Effect of low-temperature pyrolysis conditions on biochar for agricultural use. Transactions of the American society of agricultural and biological engineers, 51(6): 2061-2069

Ghani, W. A. K., A. A. Mohd, G. Silva, R. T. Bachmann, Y. H. TaufiqYap, U. Rashid and A. H. Al-Muhtaseb 2013 Biochar production from waste rubber-wood-sawdust and its potential use in C sequestration: chemical and physical characterization. Industrial Crops and Products Journal, 44: 18-24

Gheorghe, C., C. Marcuescu, A. Badea, C. Dinca and T. Apostol 2009 Effect of pyrolysis conditions on biochar production from biomass. Proceedings of the $3^{\text {rd }}$ WSEAS Int. Conf. on RENEWABLE ENERGY SOURCES, 239-241

Gundale, M. J. and T. H. DeLuca 2006 Temperature and source material influence ecological attributes of ponderosa pine and Douglas-fir charcoal. Forest Ecology and Management, 231: 86-93

Haiping Y., R. Yan, H. Chen, D. H. Lee and C. Zheng 2007 Characteristics of hemicellulose, cellulose and lignin pyrolysis. Fuel, 86: 1781-1788

Helling, C. S., G. Chesters and R. B. Corey 1964 Contribution of organic matter and clay to soil cation exchange capacity as affected by the $\mathrm{pH}$ of the saturation solution. Soil Science Society of America Proceedings, 28: 517-520

Hendershot, W. H. and M. Duquette 1986 A simple barium chloride method for determining cation exchange capacity and exchangeable cations. Soil Science Society of America Journal, 50: 605-608

Ioannidou, O. and A. Zabaniotou 2007 Agricultural residues as precursors for activated carbon production: A review. Renew. Sust. Energy Reviews, 11(9): 1966-2005

Ip, A. W. M., J. P. Barford and G. McKay 2008 Production and comparison of high surface area bamboo derived active carbons. Bioresource Technology, 99: 8909-8916

Jindo, K., H. Mizumoto, Y. Sawada, M. A. Sanchez-Monedero and T. Sonoki 2014 Physical and chemical characterization of biochars derived from different agricultural residues. Biogeosciences, 11: 6613-6621

Joseph, S. D., M. Camps Arbestain and Y. Lin 2010 An investigation into the reactions of biochar in soil. Austra. Australian Journal of soil Research, 48: 501-515

Kucukbayrak, S. and E. Kadiog lu 1989 Effect of pyrolysis on the proximate and ultimate analysis of lignite. Thermochimica Acta, 155: 1-6

Kundsen, D., G. A. Peterson and P. F. Pratt, 1982 Chemical and microbial properties. In: Methods of Soil Analysis. pp. 225-246

Kuo, W. R., J. J. Huang, N. Fujmoto and H. C. Lin 2018 Physicochemical properties of biochar prepared from agricultural and forestry processing wastes as cultural medium substance and its effect on growth quality of vegetable plug seedlings. Journal of the Faculty of Agriculture Kyushu University, Japan, 63(2): 361-370

Lehmann, J., J. Gaunt and M. Rondon 2006 Bio-char sequestration in terrestrial ecosystems-a review. Mitigation and Adaptation Strategies for Global Change, 11: 403-427

Lehmann, J. and S. Joseph 2009 Chapter 1: Biochar for envi- ronmental management: An Introduction. In: Lehmann, J. and S. Joseph (eds.), Biochar for Environmental Management: Science and Technology. Earthscan Publications Ltd., UK. pp. $1-9$.

Liang, B., J. Lehmann, D. Solomon, J. Kinyangi, J. Grossman, B. O'Neill, J. O. Skjemstad, J. Thies, F. J. Luizao, J. Petersen and E. G. Neves. 2006 Black carbon increases cation exchange capacity in soils. Soil Science Society of America Journal. 70(5): 1719-1730

Lin, H. C., Y D. Wu, C. W. Peng, G. S Hwang and W. R. Kuo 2010 Application of Moso bamboo charcoal cultural media to vegetable plug seedlings. FOREST PRODUCTS INDUSTRIES, 29(3): 59-171

Lin, H. C., Y. C. Weng, G. S. Hwang and N. Fujimoto 2014 Evaluation of adsorption and mutagenicity of activated carbons refined from charcoals. Journal of the Faculty of Agriculture Kyushu University, Japan, 59(1): 117-125

Lin, H. C. and Y. P. Huang 2016 Development of bio-functional materials from agricultural forestry processed wastes by a concept of muiti-utilization with pyrolysis. Universal Journal of Materials Science. 4(3): 65-73

Neary, D. G., C. C. Klopatek, L. F. DeBano and P. F. Ffolliott 1999 Fire effects on belowground sustainability: A review and synthesis. Forest Ecology and Management, 122: 51-71

Novak, J. M., I. Lima, B. Xing, J. W. Gaskin, C. Steiner, K. C. Das, M. Ahmedna, D. Rehrah, D. W. Watts, W. J. Busscher and H. Schomberg 2009 Characterization of designer biochar produced at different temperatures and their effect on a loamy sand. Annals of Environmental Science, 3: 195-206

Paradelo, R., A. B. Moldes and M. T. Barral 2013 Evolution of organic matter during the mesophilic composting of lignocellulosic winery wastes. Journal of Environmental Management, 116(15): 18-26

Peng, C. W. and H. C. Lin 2015 Japanese cedar ash as a natural activating agent for preparing activated carbon. Journal of Wood Science Japan, 61(3): 316-325

Reed A. R. and P. T., Williams 2004 Thermal processing of biomass natural fibre wastes by pyrolysis. International Journal of Energy Research, 28: 131-145

Steiner, C. 2007 Slash and char as alternative to slash and burn: Soil charcoal amendments maintain soil fertility and establish a carbon sink. Chemistry and Geosciences. pp. 1-5

Teng, H. and L. Y. Hsu 1999 High-porosity carbons prepared from bituminous coal with potassium hydroxide activation, Industrial and Engineering Chemistry Research, 38: 2947

Topoliantz, S., J. F. Ponge and S. Ballof 2005 Manioc peel and charcoal: A potential organic amendment for sustainable soil fertility in the tropics. Biology and Fertility of Soils, 41(1): $15-21$

Van Zwieten, L., S. Kimber, S. Morris and K. Chan 2010 Effects of biochar from slow pyrolysis of paper mill waste on agronomic performance and soil fertility. Plant Soil, 327: 235-246

Walker, P. L. and A. Almagro 1995 Activation of pre-chlorinated anthracite in carbon dioxide and steam. Carbon, 33(2): 239241

Xin, X., Z. Chen and b. Chen 2016 H/C atomic ratio as a smart linkage between pyrolytic temperatures, aromatic clusters and sorption properties of biochars derived from diverse precursory materials. Scientific Reports, 6: 22-644

Yamada, T. and H. Ono 1999 Rapid liquefaction of lignocellulosic waste by using ethylene carbonate. Bioresource Technology, 70: $61-67$

Zimmerman, A. R. 2010 Abiotic and microbial oxidation of laboratory-produced black carbon (biochar). Environ. Science and Technology of Advanced Materials, 44: 1295-1301 